\title{
TAX POTENCY ON PEER TO PEER LENDING BUSINESS
}

\author{
Irwan Aribowo ${ }^{1 \bullet}$, Hariomurti Tri Kuntonegoro ${ }^{2}$, Laily Rofi'ah ${ }^{3}$, Agus Suryono ${ }^{4}$, Khairul Muluk ${ }^{5}$, \\ Andy Fefta Wijaya ${ }^{6}$ \\ 1) irwan_aribowo@pknstan.ac.id, Polytechnic of State Finance STAN \\ 2) Directorate General of Taxation \\ 3) Master of Management Study Program, Pamulang University \\ 4) Faculty of Administrative Science Brawijaya University \\ 5) Faculty of Administrative Science Brawijaya University \\ 6) Faculty of Administrative Science Brawijaya University
}

\begin{abstract}
In 2019, the transaction value of digital economy has reached $\$ 40$ billion with a projected growth of $49 \%$ per year. One of the fast growing digital economy in Indonesia is Peer to Peer Lending (P2P Lending) fintech. The Directorate General of Taxes (DGT) as tax authority must be careful in taking the advantage of opportunities to optimize tax revenue. This study describes the exploration of tax potency in P2P lending business carried out by tax officers. The focus of this research is to find out the taxation aspects of the P2P lending business, to find out how to extract potencies carried out by the tax authorities, and to find out the obstacles in extracting tax potency in the field. The analysis used in this study is qualitative methods. The results indicate that extracting tax potency in this business is still not optimal. Factors that become obstacles in exploring the potency are the limited access to financial data of taxpayers, the absence of specific tax rules regulating the P2P lending business, and the lack of cooperation between interrelated agencies.
\end{abstract}

Keywords: Fintech, P2P Lending, Taxation

\section{INTRODUCTION}

Along with the growth rate of internet use in Indonesia, the digital economy in Indonesia is also growing very fast. Google-Temasek (Sataloff, Johns, \& Kost, 2019) in its report states that Indonesia's digital economy projections in 2025 will reach $\$ 130$ billion. In 2019, the transaction value from digital economy has reached $\$ 40$ billion with a projected growth of $49 \%$ per year. The development of digital economy, which has increased rapidly since 2017 , must be considered by the Government. The digital economy that has grown rapidly in Indonesia in the last three years, one of which is the financial technology of Peer to Peer lending ( $\mathrm{P} 2 \mathrm{P}$ lending). The P2P lending industry is a new breakthrough from conventional lending model that has been practiced by banks. In relation to the tax aspect, income on capital returns (passive income) in the form of interest received by the party providing the loan is the object of Income Tax (PPh), this refers to Law Number 36 of 2008 concerning Income Tax (PPh Law). A money lending and borrowing transaction conducted by taxpayers through P2P lending fintech platform is subject to Article 23 Income Tax (PPh) in accordance with Income Tax Law. Income Tax Article 23 is imposed on lenders (investors) with a tax withholding mechanism by the party providing income, in this case the borrower. When compared with the conventional lending model carried out by banks, the tax aspect of a P2P lending transaction has differences. For the banking industry, Income from loan yields given to banks is considered as income from banking business operations itself so that it is not subject to Income Tax Article 23. Statistical data shows that as of August 2019, disbursement of funds through fintech P2P lending has reached IDR 54.72 trillion. When compared with MSME lending through conventional banks which accumulated as of August 2019 reaching IDR 1035.5 trillion, the cumulative portion of lending through fintech is 5.3\% of total MSME credit disbursement through conventional banks. When viewed in terms of the growth in distribution of funds, the distribution of P2P lending fintech loans has increased rapidly from only Rp. 226 billion at the end of 2016, to reaching Rp. 54.72 trillion in August 2019. Meanwhile, the growth of MSME credit disbursement through conventional banks is stable at $10-11 \%$ per year. With the emergence of various innovations in the financial industry, the Government agency that needs to immediately catch this change is the Directorate 


\section{EDUCORETAX}

Volume 2 No. 1, 2022

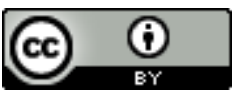

General of Taxes (DGT) as an institution for collecting state revenues. The government, especially the DGT as tax authority must be careful in taking advantage of opportunities to optimize tax revenue.

Previous research has generally discussed the taxation aspects of the P2P lending business based on literature studies on applicable tax regulations. Some of these studies also briefly discuss the absence of specific regulations that impact on the absence of legal certainty regarding taxation in $\mathrm{P} 2 \mathrm{P}$ lending business. Meanwhile, this research focuses on the tax potency aspects of the P2P lending business. This potential tax aspect includes taxation aspects both Income Tax (PPh) and Value Added Tax (PPN) as well as fulfillment of tax obligations that arise for parties involved in P2P lending transactions which generally involve lenders, providers (fintech) and the borrowers.

Based on that, the authors are interested in examining the exploration of tax potency in P2P lending business with more emphasis on the internal side of DGT as tax authority. The scope of this research includes the steps and strategies for extracting tax potency on the P2P lending business carried out by tax officers from Pratama Tax Office (KPP) in Jakarta.

\section{LITERATURE REVIEW P2P Lending}

Fintech is defined as the application of digital technology to financial intermediation problems (Aaron, Rivadeneyra, \& Sohal, 2017). Dorfleitner, Hornuf, Schmitt, \& Weber define financial technology as a very fast-moving and dynamic industry where there are many different business models (Dorfleitner, Hornuf, Schmitt, \& Weber, 2017). There are three types of fintech according to Hsueh (Hsueh \& Kuo, 2017), namely P2P lending, payment systems through third parties and crowdfunding. Meanwhile, Bank Indonesia classifies fintech into four types, namely, a) crowdfunding and P2P Lending, b) market aggregator, c) risk and investment management, and d) payment, settlement and clearing.

According to Ge, Feng, Gu, \& Zhang (Ge, Feng, Gu, \& Zhang, 2017), P2P lending is a process of borrowing money between two unrelated individuals directly through an online platform, without interference from traditional financial intermediaries such as banks. Dorfleitner et al. stated that P2P lending is a major innovation related to banking sector (Dorfleitner et al., 2017). In recent years, the number of platforms offering the service and the number of transactions has continued to increase. According to Hsueh (Hsueh \& Kuo, 2017), P2P lending is an internet-based business model that meets loan needs between financial intermediaries. This platform is aimed for entrepreneurs as well as medium and small companies where they think bank loan requirements may be too high.

Prof. Dr. Rochmat Soemitro in Mardiasmo (Prof. Dr. Mardiasmo, Mba., 2011) defines taxes as "... people's contributions to the State treasury based on law (which can be enforced) without receiving reciprocal services (counter-achievement) which can be directly demonstrated and which are used to pay for general expenses." Whereas Andriani in Waluyo (Waluyo, 2018), states that taxes are dues to the state (which can be enforced) owed by those who are obliged to pay them according to regulations, without re-achievement, which can be immediately appointed, and whose use is to finance general expenditures related to State tasks carried out by the Government.

In Law Number 6 of 1983 concerning General Provisions and Tax Procedures, as amended by Law Number 16 of 2009, tax is an obligatory contribution to the State owed by an individual or entity that is compelling under the Law, by not getting direct compensation and being used for the needs of the State for the greatest prosperity of the people. Tax collection carried out by the Government must be based on certain principles. Adam Smith (Smith \& Smith, 2014)in his book, Wealth of Nations, states that there are four principles used (called Four Maxims), namely:

a. The principle of equity, or the principle of justice, means that tax collection carried out by the Government must be in accordance with the ability and income of taxpayer.

b. The principle of Certainty, or the principle of legal certainty, means that tax collection must be carried out in accordance with applicable laws and other rules, so that if someone commits a violation, legal action can be given.

c. The principle of convenience of payment or the principle of Timeliness, means that tax collection must be carried out at the right time or the best for the taxpayer.

d. The principle of Efficiency, or the principle of economy, means that tax collection is attempted at the minimum possible cost (not exceeding the value of tax collection). 


\section{EDUCORETAX}

Volume 2 No. 1, 2022

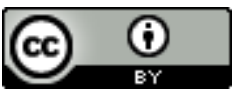

The taxation system in Indonesia adopts a self-assessment system which means that taxpayers are given the flexibility to carry out their tax obligations, namely calculating, depositing, and reporting their own taxes (Maulida, 2018). In the self-assessment system, tax officials act as supervisors (control), consultants, tax auditors and educators for taxpayers in carrying out their tax obligations. Taxpayer's potential exploration itself is an active effort made by Directorate General of Taxes by analyzing the difference between potency and data obtained from taxpayers. The excavation of tax potency is basically part of a tax control carried out by tax authorities to each taxpayer. In general, tax potential exploration approach is divided into two, namely macro approach and micro approach. The macro approach is an approach that seeks at the overall tax potency by taking into account the growth and prospects of the business sector whose potential will be explored. Meanwhile, the micro approach seeks more at the financial capacity of each of the taxpayers themselves. DGT Head Office usually determines priority sectors for potential exploration based on tax gap analysis. Tax gap is the difference between the amount of taxpayer's obliged tax within a certain period of time with the taxes that have been paid. In practice, the spearhead of this potential exploration function is carried out by Account Representatives (AR) who are in charge of the Supervision and Consultation section, as well as in the Extensification and Counseling section specifically to deal with new taxpayers. Supervision as one of the main duties of the Directorate General of Taxes basically includes research and inspection activities in the field of taxation based on the Circular of the Director General of Taxes Number SE-05 / PJ.07 / 2004. The function of supervising and extracting tax potency is carried out by AR as stipulated in the Minister of Finance Regulation Number PMK 79 / PMK.01 / 2015 concerning Account Representatives.

OJK deputy commissioner, Sukarela Batunangar on March 26, 2019, said that prior to the P2P lending fintech, MSMEs had difficulty obtaining capital because their business was not too big, making these MSME actors not bankable (Hartomo, 2019). The practical aspect offered by fintech P2P lending is a special attraction for the public. Besides being practical, this business also offers a fairly large Return on Investement (ROI) for investors and loans with competitive interest rates for borrowers.

With the continuous development of digital economy from year to year, it can be said that this phenomenon is a potential new tax revenue that must be immediately executed by tax authorities. AR in charge of exploring potential needs to optimize tax revenue from the P2P lending business to cut the gap between target and realization of tax revenue, especially from the intensification sector through supervision of taxpayers and tax extensification in order to achieve tax revenue targets. The expertise of tax authorities in exploring the potency for tax revenue is very crucial for the achievement of tax revenue targets while still paying attention to aspects of economic justice. Fintech P2P lending has been regulated in Presidential Regulation (Perpres) Number 82 of 2016 concerning the National Strategy for Financial Inclusion (SNKI). One of the Government's targets is to increase financial inclusion which is focused on low-income people, Micro, Small and Medium Enterprises (MSMEs), and cross-group communities.

\section{METHOD}

This research uses a qualitative approach with descriptive research type. Sugiyono (Sugiyono, 2016) explains that qualitative methods are used to understand the meaning behind visible data, develop theories, ensure the correctness of data, and examine the history of development. In addition, qualitative research also aims to find interactive relationship patterns, discover theories, describe complex realities, and gain an understanding of meaning. Yin (Yin, 2014) explains that qualitative methods have advantages because of their ability to present views and perspectives in research.

Primary data collection will be carried out by conducting in-depth interviews with several related sources. Determination of data sources on interviewees was carried out purposively which is selected with certain considerations and goals (Sugiyono, 2016). Secondary data in this study are data and information obtained from various sources, such as books, journals, reports, news in the media, research results, and regulations related to exploring tax potency in $\mathrm{P} 2 \mathrm{P}$ lending business.

The author performs data processing according to the interactive method described by Huberman (Huberman \& Miles, 2012). The steps in the interactive method are carried out continuously until the data becomes saturated. 
Figure 1. Components of Data Analysis

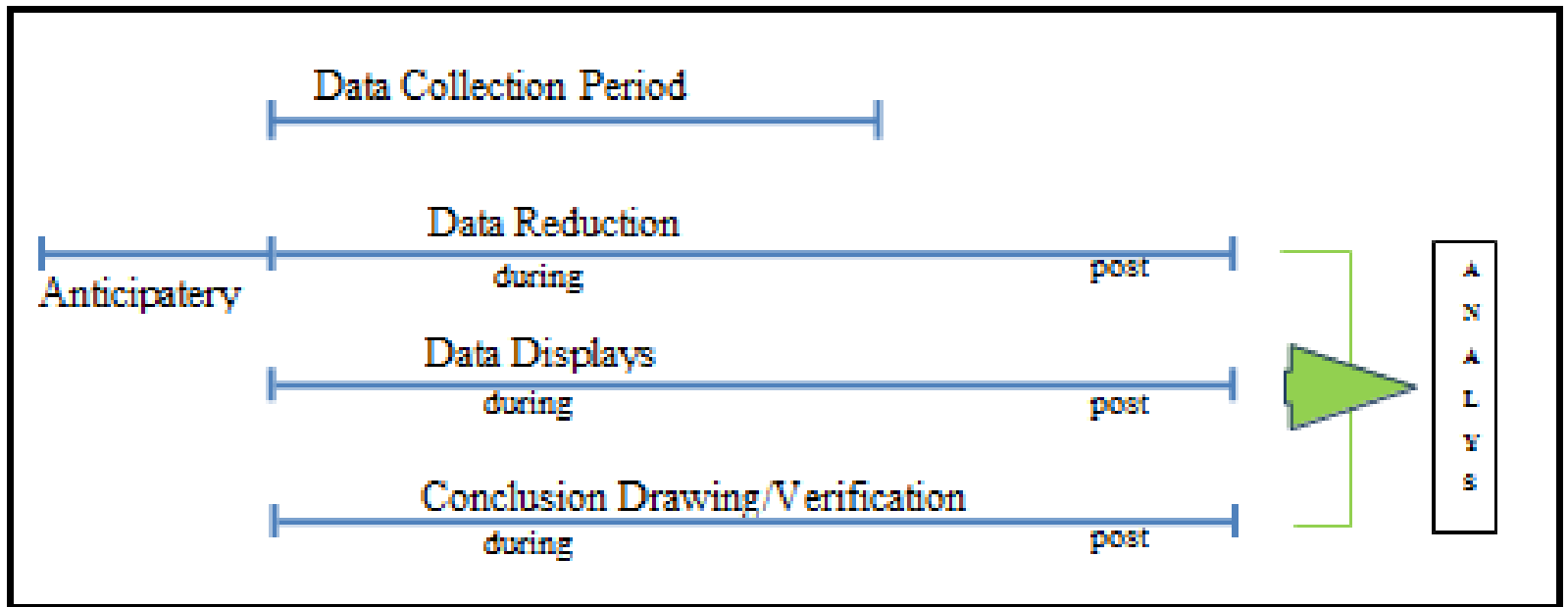

Source: Miles and Huberman.

Qualitative data analysis methods must be systematic and comprehensive, dynamic, accessible, allow comparison, and transparent (Miles \& Huberman, 1994). Therefore, to process primary data from interviews in qualitative research, there are several stages of analysis that must be carried out by the author, namely:

1. Recognizing data (Immersion),

2. Identifies the piece of data of interest and provides an index so that it is easy to find (first coding),

3. Collecting similar data in one table to see any typology or concept (second coding),

4. Collecting similar data with themes that will be used in making research results (third coding), and

5. Build themes, ideas, and discussion of research results (Interpretation).

\section{RESULT AND DISCUSSION}

P2P Lending fintech entrepreneurs in Indonesia are members of the Indonesian Joint Funding Fintech Association (AFPI). AFPI is an official association of information technology-based lending and borrowing services in Indonesia. Any legal fintech platform must be a member of AFPI, be licensed and / or registered with the Financial Services Authority (OJK). As a means of regulating the P2P lending fintech business process, the AFPI code of ethics stipulates that loan interest on P2P lending transactions is a maximum of $0.8 \%$ per day. This amount consists of interest, interbank transfer fees, verification fees, fines and others. AFPI also stipulates that the accumulation of all costs including penalties is $100 \%$ of principal amount of the loan. 


\section{EDUCORETAX}

Volume 2 No. 1, 2022

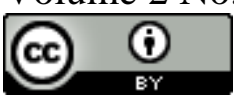

Figure 2. Fintech P2P Lending Business Process in Indonesia

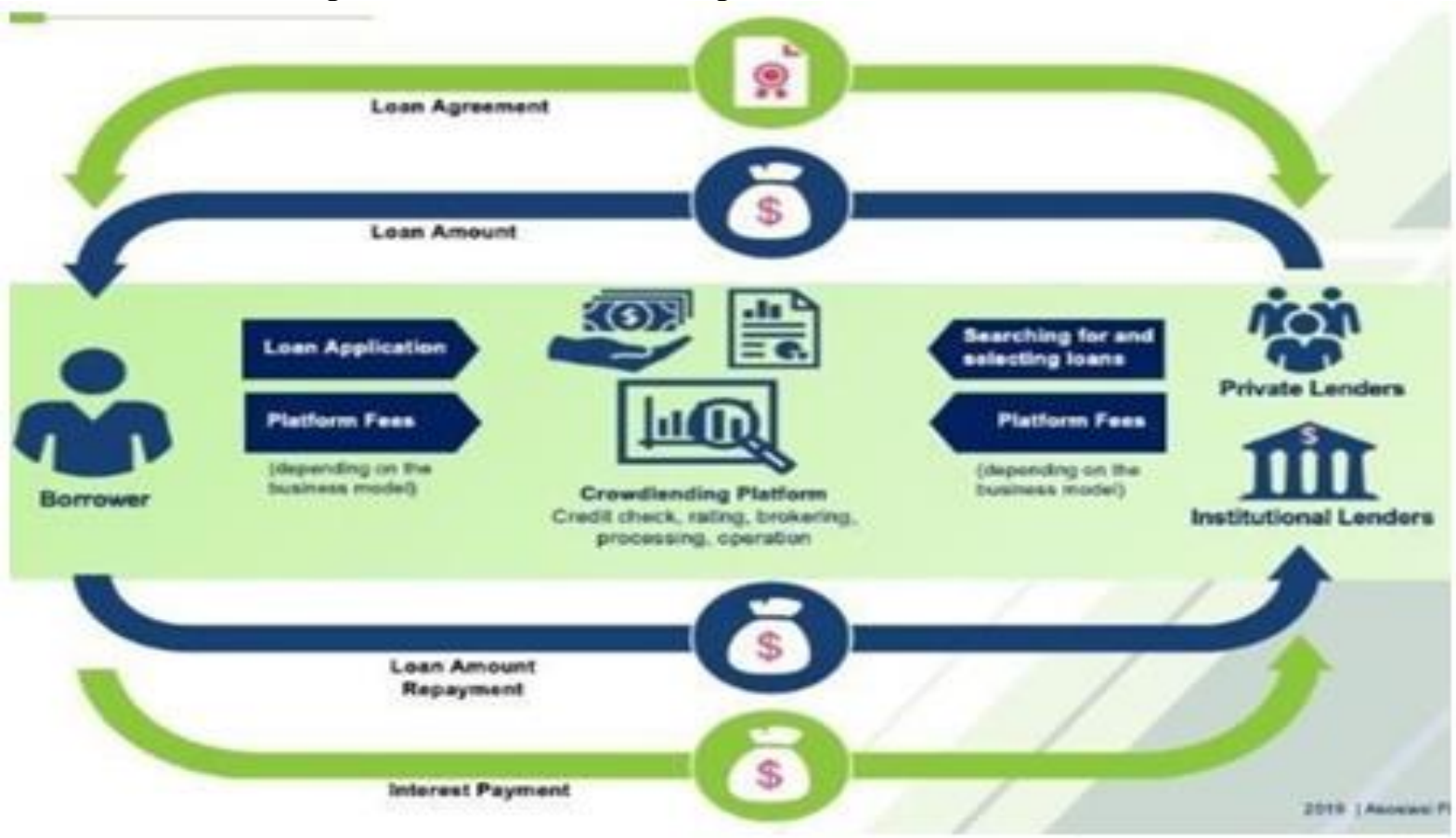

Source: The Indonesian Joint Funding Fintech Association (AFPI) 2019.

The function of $\mathrm{P} 2 \mathrm{P}$ lending platform is as an intermediary or liaison that brings together investors and borrowers. Unlike financial services in banking business, the risk of credit or default in this business is fully borne by the lender and no state institution or authority is responsible for this risk of default. To ensure that this lending and borrowing service runs well, the P2P lending platform is required to make transactions through an escrow account or virtual account according to the provisions of the OJK. The organizer maintains the credibility of P2P lending platform by selecting prospective borrowers who apply for loans with a grade scoring mechanism.

To support the research, interviews were conducted with nine different resource persons who have competency expertise in their respective fields. Resource persons in this study consisted of Directorate General of Taxes (DGT), practitioners, academics, and tax observers.

The list of questions used in this study are categorized into four main parts, namely general questions, questions about the taxation aspects of $\mathrm{P} 2 \mathrm{P}$ lending fintech business, questions related to the process of extracting tax potency by AR, this question is specifically asked to AR which in real terms supervise and explore the potency of Taxpayers engaged in P2P lending. The last category is questions related to constraints and challenges in the field related to potential exploration process.

\section{Analysis of Taxation Aspects in P2P Lending Business}

A business process that uses economic resources basically has the aim of increasing the wealth of business owner. Each additional economic capacity or income will be taxed as referred to Law Number 36 of 2008 concerning Income Tax. The author asks questions directly to the sources, thus, the authors get answers to research questions related to tax aspects of this P2P lending fintech business.

Table 1. Recapitulation of resource persons' answers to question code A-01

\begin{tabular}{|l|l|}
\hline $\begin{array}{l}\text { Question code A- } \\
\text { 01 }\end{array}$ & $\begin{array}{l}\text { What are the taxation aspects that can be explored in the P2P } \\
\text { Lending transaction? }\end{array}$ \\
\hline Interviewees & Answer \\
\hline YPH & Income Tax, VAT \\
\hline DP & Income Tax \\
\hline M N & Income Tax \\
\hline NH & Income Tax \\
\hline MT & Income Tax \\
\hline
\end{tabular}


EDUCORETAX

Volume 2 No. 1, 2022

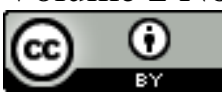

\begin{tabular}{|l|l|}
\hline AB & Income Tax \\
\hline DS & Income Tax \\
\hline RH & Income Tax, VAT \\
\hline MCA & Income Tax \\
\hline
\end{tabular}

Source: compiled by the author

Questions with code A-01 were asked to all informants in this study. All informants stated that basically the definite tax aspect of the P2P lending business is Income Tax (PPh) aspect.

\section{Exploring Tax Potency in P2P Lending Business}

Potential exploration is an active effort by DGT by analyzing the differences between potencies and the data obtained based on taxpayers' profile. Exploring the potency in P2P lending business in Indonesia is entirely the domain of Pratama Tax Service Office (KPP). Based on the data obtained by the author, all taxpayers who are registered as P2P lending taxpayers are in KPP Pratama assignment area. YPH and DP are of the opinion that fintech P2P lending in Indonesia only started to develop in 2017. YPH said that in that year tax payments from taxpayers engaged in P2P lending sector began to grow. Based on this phenomenon, it can be said that basically the process of exploring the potency in this sector has not been carried out for too long. There are not many ARs who handle taxpayers in this sector. The distribution of taxpayers who have this line of business is still centered in the capital city of Indonesia and their tax obligations are handled / supervised by AR who is on duty in the DKI Jakarta Province. The excavation of tax potency is basically part of a tax control carried out by tax authorities to each taxpayer. One of the ways to explore tax potency can be done by extracting tax potency based on profile. Lubis (Irwansyah, 2011) states that the success of this potential exploration is determined by the quality of the taxpayer's profile, the availability of data, and the ability to analyze and evaluate the profile carried out by the tax authorities.

\section{Constraints and challenges faced by DGT}

The task of collecting state revenue carried out by the Directorate General of Taxes is a major task that must be carried out optimally by adhering to the rules and principles of taxation in Indonesia. DGT, through tax authorities who work in the field, are bound to encounter obstacles in the process of collecting state revenues. These constraints include those that have been risk mitigated or those that have not.

Table 2. Recapitulation of resource persons' answers to questions on code K-01

\begin{tabular}{|l|l|}
\hline $\begin{array}{l}\text { Question code } \\
\text { K-01 }\end{array}$ & $\begin{array}{l}\text { One of the focuses of the 4.0 industrial revolution is the development of the } \\
\text { digital economy. Along with this, what are the obstacles faced by the tax } \\
\text { authorities in exploring potency in this business? }\end{array}$ \\
\hline Interviewees & Answer \\
\hline AB & Rapid change in business models, self-assessment \\
\hline DS & Taxpayer transaction speed \\
\hline MT & Data access \\
\hline MCA & Quick understanding of the business model, determine the value of the data \\
\hline RH & Regulations that haven't captured the digital economy yet \\
\hline YPH & Unclear regulations, limited data access \\
\hline DP & Confirm data \\
\hline M N & There is no cover system yet, limited data access \\
\hline NH & Lack of data \\
\hline
\end{tabular}

Source: compiled by the author

\section{CONCLUSION}

Due to such rapid technological developments, it seems that it will be difficult for DGT to adjust its tax regulations quickly. It is possible that the existing rules have not been able to anticipate changes in very dynamic business processes in the field, whether it is a completely new business process or a business process (probis) that is blended with old business processes, or even problems that have never thought before. Problems related to digital taxation do occur in every country. The Omnibus Law, which is currently being drafted by the Government and Parliament, is expected to be able to solve the problems of digital taxation that exist today. Until now, what Account Representatives can do as the spearhead in 


\section{EDUCORETAX}

Volume 2 No. 1, 2022

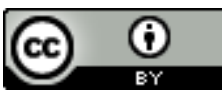

collecting state revenue is to continue to improve their analytical skills and update information related to the digital tax business. DGT as tax authority has the responsibility to provide comprehensive tax education to parties involved in this digital business. Not only limited to education on digital tax aspects, but also education on taxation in general is very important. Education that is right on target about the role of taxes to the public is one of the keys to achieving successful tax revenue. Most of the contribution of state revenue is carried out through self-assessment by taxpayers, therefore education is a means for DGT to increase awareness of taxpayers.

\section{REFERENCES}

Aaron, M., Rivadeneyra, F., \& Sohal, S. (2017). Fintech: Is This Time Different? A Framework for Assessing Risks and Opportunities for Central Banks. Bank of Canada Staff Discussion Paper, 10, 1-32. Retrieved from www.bank-banque-canada.ca

Dorfleitner, G., Hornuf, L., Schmitt, M., \& Weber, M. (2017). FinTech in Germany. In FinTech in Germany. https://doi.org/10.1007/978-3-319-54666-7

Ge, R., Feng, J., Gu, B., \& Zhang, P. (2017). Predicting and Deterring Default with Social Media Information in Peer-to-Peer Lending. Journal of Management Information Systems, 34(2), 401424. https://doi.org/10.1080/07421222.2017.1334472

Hartomo, G. (2019). OJK: Fintech Salurkan Pembiayaan ke UMKM Tembus Rp25,9 Triliun. OkeFinance. Retrieved from https://economy.okezone.com/read/2019/03/26/320/2035162/ojkfintech-salurkan-pembiayaan-ke-umkm-tembus-rp25-9-triliun

Hsueh, S. C., \& Kuo, C. H. (2017). Effective matching for P2P lending by mining strong association rules. ACM International Conference Proceeding Series, Part F130952, 30-33. https://doi.org/10.1145/3133811.3133823

Huberman, A., \& Miles, M. (2012). Understanding and Validity in Qualitative Research. In The Qualitative Researcher's Companion (pp. 36-64). https://doi.org/10.4135/9781412986274.n2

Irwansyah, L. (2011). kreatif gali sumber pajak tanpa bebani rakyat. Jakarta Elex Media Komputindo.

Maulida, R. (2018). Sistem Pemungutan Pajak di Indonesia. Retrieved from online pajak website: https://www.online-pajak.com/tentang-pajak-pribadi/sistem-pemungutan-pajak

Miles, M., \& Huberman, A. (1994). Miles and Huberman. In Qualitative Data Analysis: An expanded sourcebook.

Prof. Dr. Mardiasmo, Mba., A. (2011). Perpajakan Edisi Terbaru 2016. In Penerbit ANDI.

Sataloff, R. T., Johns, M. M., \& Kost, K. M. (2019). e-Conomy Sea 2019. Google Temasek , Bain \& Company, 1-65.

Smith, A., \& Smith, A. (2014). An Inquiry into the Nature and Causes of the Wealth of Nations. In The Glasgow Edition of the Works and Correspondence of Adam Smith, Vol. 2: An Inquiry into the Nature and Causes of the Wealth of Nations, Vol. 1. https://doi.org/10.1093/oseo/instance.00043218

Sugiyono, P. D. metode penelitian kuantitatif, kualitatif,dan R\&D. , Alfabeta, cv. 233(2016).

Waluyo. (2018). Perpajakan Indonesia. In Yogyakarta: Andi.

Yin, R. K. (2014). Case Study and Research :Design and Method. In SAGE Publications.Inc. 